Article

\title{
Fits-and-Starts: The Changing Nature of the Material City
}

\author{
Aseem Inam \\ Welsh School of Architecture, Cardiff University, UK; inama1@cardiff.ac.uk
}

Submitted: 10 May 2021 | Accepted: 4 September 2021 | Published: 11 January 2022

\begin{abstract}
How and why does the material city in the late 20th and early 21st century change? This article examines one type of prominent urban change, which is "fits-and-starts" and represents change that is concentrated in space and time and that nonetheless has longer term repercussions with high economic and environmental costs. Through a review of the literature and an illuminating case study in Las Vegas, this article reveals how human perception and decision-making via two interrelated phenomena, future speculation and manufactured obsolescence, drive such change. The case study in Las Vegas is particularly fascinating because as a city of apparent extremes, it not only reveals in clear relief phenomena that are present in the capitalist city but it also offers insights into basic patterns of decision-making that actually shapeor design - the contemporary city. The article concludes with more general insights into the nature of this type of urban change and implications for alternative types of urban practices.
\end{abstract}

\section{Keywords}

fits-and-starts; Las Vegas; material city; urban change; urban practice

\section{Issue}

This article is part of the issue "City as Flux: Interrogating the Changing Nature of Urban Change" edited by Aseem Inam (Cardiff University).

(C) 2022 by the author(s); licensee Cogitatio (Lisbon, Portugal). This article is licensed under a Creative Commons Attribution 4.0 International License (CC BY).

\section{Introduction}

Historically, cities were thought to have changed gradually, much like the metaphor of a slowly flowing river that changes course over centuries and millennia. In contrast, this research makes the claim that prominent parts of the contemporary city often change in fits-and-starts, which are sporadic bursts of activity that are concentrated in time and space but that nonetheless have long-lasting consequences. In the cities of late 20th and early 21st century within capitalist economies, sudden and large-scale changes to the urban fabric occur often due to speculation about increased future profits as structurally sound buildings are replaced by newer and larger ones. The famed Las Vegas Strip is renowned for the regular implosions of buildings that are only a few decades old. The Las Vegas Strip, or simply "the Strip," is the popular name for the South Las Vegas Boulevard, where most of the major casino-hotel-resorts are concentrated. This research examines the demolitions and construction on the Las Vegas Strip to understand the perceptions and calculations of future profit and to tease out the thinking behind fits-and-starts type of urban change. The location of the case study in Las Vegas (i.e., the Las Vegas metropolitan region) is particularly insightful because this city of extremes brings into sharp relief those phenomena that characterize the urbanism of the contemporary city.

I approach urbanism via the lens of materiality, which is the quality or state of being that consists of matter and which relates to the physical world (Beauregard, 1990). In cities, there are many different terms for this, such as urban form, urban landscape, urban fabric, and built environment. I prefer the term material city to refer to the world of things that embody the four-dimensional city, which are the three dimensions of physical form plus the fourth dimension of time that form inhabits and changes within. At a most basic level, the materiality of the city is that which we human being perceive; that is, the actuality that we see, touch, feel, and hear with immediacy. In fact, while the city can be thus perceived as a world of things that we perceive and interact with 
(e.g., land parcels, buildings, open space, and infrastructure that are the most commonly identified spatial and formal elements of urbanism), the city as a whole (i.e., which is what I call a metropolitan region in this context) can also be considered to be an immense actor of its own that we humans have brought into being (Fletcher, 2012). My focus here is on how the most primary forms and spaces that tend to define both the basic material as well as the primary commodities of capitalist urbanism-i.e., buildings and the parcels of land they occupy-operate over time in recent history. The material city has multiple aspects and meanings (Lieto, 2017), but even at its most basic level, it matters a great deal because it is the spatial, tangible, and textured setting of our daily lives and its meanings can have great impacts.

The selection of the case study in Las Vegas is based on Flyvbjerg's (2006) compelling argument about the "force of the example," in which a case study illuminates concrete reality through thick descriptions and rich narratives. Las Vegas is an excellent site for such qualitative and fine-grained analysis of contemporary urbanism (e.g., Inam, 2016) because of the way its apparent extremes reveal-with great clarity-what occurs in other cities (e.g., historical relationalities as turning points in urbanism, public-private partnerships that are structurally imbalanced, frontstage/backstage metaphors that reveal spatial inequalities). As a city of extremes, Las Vegas is also an excellent site to study how and why such patterns of fits-and-starts urban change occurs. For example, between 1993 and 2016, in a highly accelerated version of the change that many U.S. cities experience, Las Vegas demolished significant hotels, casinos, and resorts: the Dunes, Landmark, Sands, Hacienda, Aladdin, El Rancho, Desert Inn, Boardwalk, Stardust, New Frontier, Riviera, and Clarion. They were replaced by new icons of the Las Vegas Strip, such as the Bellagio, Venetian, Mandalay Bay, Planet Hollywood, Wynn, and CityCenter casino-hotel-resorts. Thus, by using the example in Las Vegas as an illuminating case study, the research in this article helps us understand that it is ultimately, human beings (e.g., investors, property owners, developers) who make decisions based on their perceptions of current versus future economic values. I now examine the various discussions of the changing material city in the literature.

\section{City as Flux: Understanding Urban Change}

Urban change is commonplace, as I describe in my book Designing Urban Transformation (Inam, 2014). Much of what follows draws from and builds upon that work and its related literature. There is a mode of thinkingespecially in the design fields and among practitionersthat tends to value the city primarily as a fixed threedimensional object. The conventional mindset in which cities are designed has been shaped by an architectural vision that seeks to articulate urban environments in minute detail (Hack, 2011, p. 446). The underly- ing idea is that a stable framework for urban life will offer a semblance of continuity in the face of the everchanging occupants and activities of the material city. In order to operationalize this approach, urbanists have devised a variety of techniques, such as design guidelines, form-based development regulations, signage controls, pattern books, and design review processes managed by committees. While such an approach often produces visionary thinking and stunning visualizations, it nonetheless posits an objectified endpoint for a phenomenon (i.e., the city) that is in reality constantly changing, and thereby limits a multitude of possibilities in its further evolution.

Scholars of urbanism have made a similar argument regarding our understanding of cities, including the historian Spiro Kostof:

The tendency all too often is to see [the material city] as a finite thing, a closed thing, a complicated object. I want to stress what we know instead to be the casethat a city, however perfect its initial shape, is never complete, never at rest. Thousands of witting and unwitting acts every day alter its lines in ways that are perceptible only over a certain stretch of time. City walls are pulled down and filled in; once rational grids are slowly obscured; a slashing diagonal is run through close-grained residential neighborhoods; railroad tracks usurp cemeteries and waterfronts; wars, fires, and freeway connectors annihilate city cores. (Kostof, 1999, p. 13)

Other scholars have forged ahead with their own investigations of such shifts. For example, in 1915, the biologist, sociologist, and pioneering town planner, Patrick Geddes, argued that "a city is more than a place in space, it is a drama in time" (Geddes, 1915, p. 107). The geographer James Vance focused on what he called "urban morphogenesis-the creation and subsequent transformation of city form" (Vance, 1990, p. 38). Although urban morphology is often taken simply to mean the physical form of the city, Vance addressed the questions of process, such as how a society creates and transforms the physical fabric of the city.

The geographer David Harvey is even more explicit about describing the city as flux when he discusses the process of the "destruction, invasion, and restructuring of places on an unprecedented scale," caused by "changing material practices of production, consumption, information flow, and communication coupled with the radical reorganization of space relations and of time horizons within capitalist development" (Harvey, 1990, p. 39). Technological innovations in production and advanced differentiation in consumption speed the pace at which commodities, including buildings, are produced, junked, and reproduced (Harvey, 1990). Moreover, for Harvey the city is more of a means than an end in and of itself, due to production driven by motives of capital accumulation: "The urban process implies the creation of a 
material physical infrastructure for production, circulation, exchange and consumption" (Harvey, 1978, p. 113).

The question arises, then, of how exactly this notion of city as flux manifests in the material city. Kostof provides a vivid description of this physical manifestation:

The spatial order cast by houses, monuments, and solid city walls is gradually subverted by generations of seemingly innocuous tinkering, as in the case of Rome, or its deliberately revamped through massive interventions, like those of Haussmann's Paris. In recent times, modern warfare's generous capacity to destroy has been seized as an opportunity to experiment with the latest trends in urban design: lacking a war, mass demolitions can be legislated to similar ends. (Kostof, 1999, p. 280)

Furthermore, "far less dramatic is the incremental transformation of city form through the thousands of daily adjustments to its fabric due to the owners and users of private property" (Kostof, 1999, p. 250).

At different scales of time, by the hour, the day, the month, the year, the decade and beyond, the material city is therefore always in a state of flux. Architect and theorist Rem Koolhaas called this state delirious (Koolhaas, 1978), while urban theorist Marshall Berman wrote that the experience of the urban is not only fleeting but a type of perpetual disintegration that is part of the maelstrom of modern life (Berman, 1982). Both Koolhaas and Berman's observations speak very much about the contemporary city in the late 20th and early 21st centuries. In this era more than any other, technological innovations in production, globalization, and advanced differentiation in consumption accelerate the pace at which commodities, including the buildings, spaces, and infrastructure of urbanism, are produced, eliminated, and reproduced. The implication is that cities are changing at a faster rate than in the past. At the same time, different parts of the city change at different rates, such as underlying topographies and geographies of land (e.g., hills, rivers, water table), plots of land ownership, and certain infrastructures such as roads and sewage systems that can sometimes last for well over a hundred years. Cities represent massive sunk costs not only in large-scale fixed capital, such as buildings and bridges, but also in the economic and political arrangements that have evolved to manage that capital. Buildings themselves are spatially entrenched commodities whose qualities (e.g., sunk costs, land use regulations, three-dimensional materiality) resist frequent mutation and thus are slower to change. At the other extreme, within buildings, office and retail interiors tend to change more frequently.

The materiality of a city does not inherently behave like either regular radio waves whose rhythms recur or like organic pieces of fruit whose eventual decay is inevitable. If we look more to empirical social science than to metaphors borrowed from the physical sciences, the rhythms of change appear less regular and more dependent on the decisions made by key actors within specific social, economic, and political processes and contexts. The conventional paradigm that forms the foundation of real estate economics and is the starting point for most neoclassical models of property markets is basically about supply and demand (Weber, 2015). Change is driven by the current and potential users of space who seek to maximize their utility; in other words, cycles are market-driven and demand-derived, such as from the household formation, job growth, and business growth. In these demand-side explanations, construction cycles are driven by the aggregation of individual occupants' profit-maximizing decisions to move or expand in competitive markets. However, if real estate is indeed simply derived demand, then spatial change should closely mimic trends in population, net household formation, and employment.

In contrast, supply-side perspectives tend to view buildings as vehicles through which property owners and others in the industry make money. Construction occurs when the assets produced are considered a good investment. The profitability of construction as an investment strategy will depend not just on what individual occupants want, but also on broader institutional dynamics such as the legalities of property ownership, the cost of capital, the regulatory landscape, and the political power structures of cities. Yet another perspective, critical theory, as brilliant as it is in providing insights into the many deeply structural pitfalls of capitalism, nonetheless tends to restrict the agency of developers by treating them as tools of capital and regarding real estate as a passive outlet for the surpluses generated in other sectors (e.g. Harvey, 1978, 1990, 1991). In this perspective, developers are driven by the innate needs of capital to switch between different circuits of accumulation and root out the highest profits.

The fits-and-starts type of urban change, which is the focus of this article, suggests more sudden transitions from one state of urbanism than what conventional real estate market thinking suggests. Based on many years of my own professional experience working with developers in different parts of the world and research conducted by my colleagues and I on the role of developers in the shaping the material city in the U.S. (e.g., Inam, 2012; Inam et al., 2004; Levine \& Inam, 2004), we found that urban change can be quite idiosyncratic because it is ultimately derived from human decision-making based on perceptions, which are in turn and to various degrees informed by previous experience, peer actions, and larger political and economic trends. Rather than broadbrush theoretical generalizations derived singularly from mainstream market economics, real estate development literature, or critical theory perspectives, I thus take a more fine-grained empirical and contextually grounded approach. In this approach, while private investors and developers may be a part of a larger real estate industry that comprises other influential and interdependent 
actors, the final decision whether or not to proceed with their multimillion-dollar speculative projects rests ultimately with them and their teams, and thereby depends on their estimations regarding perceived obsolescence and speculation about future profit. In other words, the ultimate decision whether or not to purchase a property, whether or not to demolish an existing structure, and whether or not to proceed with a new building rests quite often with real estate developers, property owners, and/or financial investors themselves.

Who are the most influential decision-makers that are quite often also the main actors driving change in the material city? At first glance, it may seem to be real estate developers, but behind the scenes, there are others with access to more resources, including private investors and property owners (Feagin, 1982). Developers get funds from sources such as profits from previous projects, personal funds, borrowed funds from investors, or loans from banks and other financial institutions. The financial capitalists that provide these funds include commercial banks, pension funds, insurance companies, and foreign investors (Feagin \& Parker, 1990). In the U.S., land-use and development decisions are governed by a capitalistic political-economic system. The fact that small groups of wealthy and powerful actors can do far more than simply outbid their competitors is not analyzed in the mainstream real estate development and business literatures. Powerful actors such as wealthy speculators and industrial capitalists can and do shape the rules of the market system within which ostensibly free competition is taking place, including by influencing the public policy frameworks that have a direct bearing on their transactions. One type of real estate speculator is defined as an entrepreneur or corporate entity that purchases real estate with the hope of a profit from rising land and property values (Malpezzi \& Wachter, 2005). These speculators are investors who buy and sell for a profit in a capitalist market system, often buying up land and sitting on it, often for years until the time is ripe to sell for a hefty profit. Speculation in this sense is intimately bound up with the question of the optimal timing of development.

The simultaneous destruction and construction in fits-and-starts type of urban change is akin to Schumpeter's (1942) idea of creative destruction, in which the tendency of capitalism is to render old products obsolete and to destroy them so that it can then continually invent new ones. Thus, annihilation and innovation tend to occur together in time and certain periods experience a disproportionate amount of both, such as when spectacular changes are made to the material city. Capital thus thereby circulates through the city in ways that are both dynamic and erratic in its ceaseless search for profit. Creative destruction is subject to other factors in addition to the drive to maximize private profit, especially how key actors in this process perceive existing circumstances (e.g., as a crisis or an opportunity, or both) and social status in pursuing marketable prestige (e.g., new and supposedly more upscale projects), with the key word being "perceive." The perceptions that investors, property owners, and real estate developers have are neither standardized nor unchanging. Instead, they rely heavily on the determinations made by communities of technical experts, such as appraisers and market analysts, but speculation, luck, political influence, and class resistance also conspire to translate this process of value creation and destruction. In addition, within each local context, a lattice of state and non-state institutions influence value in the built environment (Weber, 2002).

The notion of creative destruction brings to mind the point that much of the research and practice in urbanism and its related fields (e.g., architecture, landscape architecture, urban design, real estate development, city planning) tends to focus on further construction and growth, even if it is infill types of growth. On the other hand, a significant correlate of urban growth is the often overlooked and intimately related topic of destruction; that is, demolition. The lifespan of buildings continues to decrease while demolition is increasingly a highly profitable business. For example, in 2005 , the U.S. the average life of a building was about 35 years and the business of demolition grossed more than $\$ 3$ billion (Byles, 2005). There are many types of demolition techniques, and while the Las Vegas style of implosion is an efficient and economical method demanding technical precision, spectacular entertainment for onlookers, a feast for the media, and a boon to publicity-conscious real-estate developers, it accounts for only about $1 \%$ of all contemporary demolitions. Perhaps the most significant aspect of demolition is that while many would like to think of cities as more or less solid and enduring, demolition is a practice that makes powerfully evident their vulnerability and potential mortality. I now discuss how these dynamics operate in the specific context of a city in a two-part case study analysis. Part one examines the overall fits-and-starts type of urban change between 1993 and 2016 on the Strip, and part two examines more in-depth the decision-making behind radical changes on one of the sites on the Strip, which is the Desert Inn, subsequently replaced by the Wynn Las Vegas.

\section{Case Study, Part 1: Fits-and-Starts on the Las Vegas Strip (1993-2016)}

Since the 1990s, Las Vegas has become renowned for spectacularly imploding buildings (i.e., controlled explosions in which a building collapses on itself) that are only a few decades old (see Figure 1):

The city is so attuned to change that perfectly sound buildings have been regularly torn down to make room for new structures.... Not lingering in nostalgia, developers would destroy their previous creations for the next new thing, earning Las Vegas the title "Implosion Capital of the World." (Al, 2017, p. 2) 


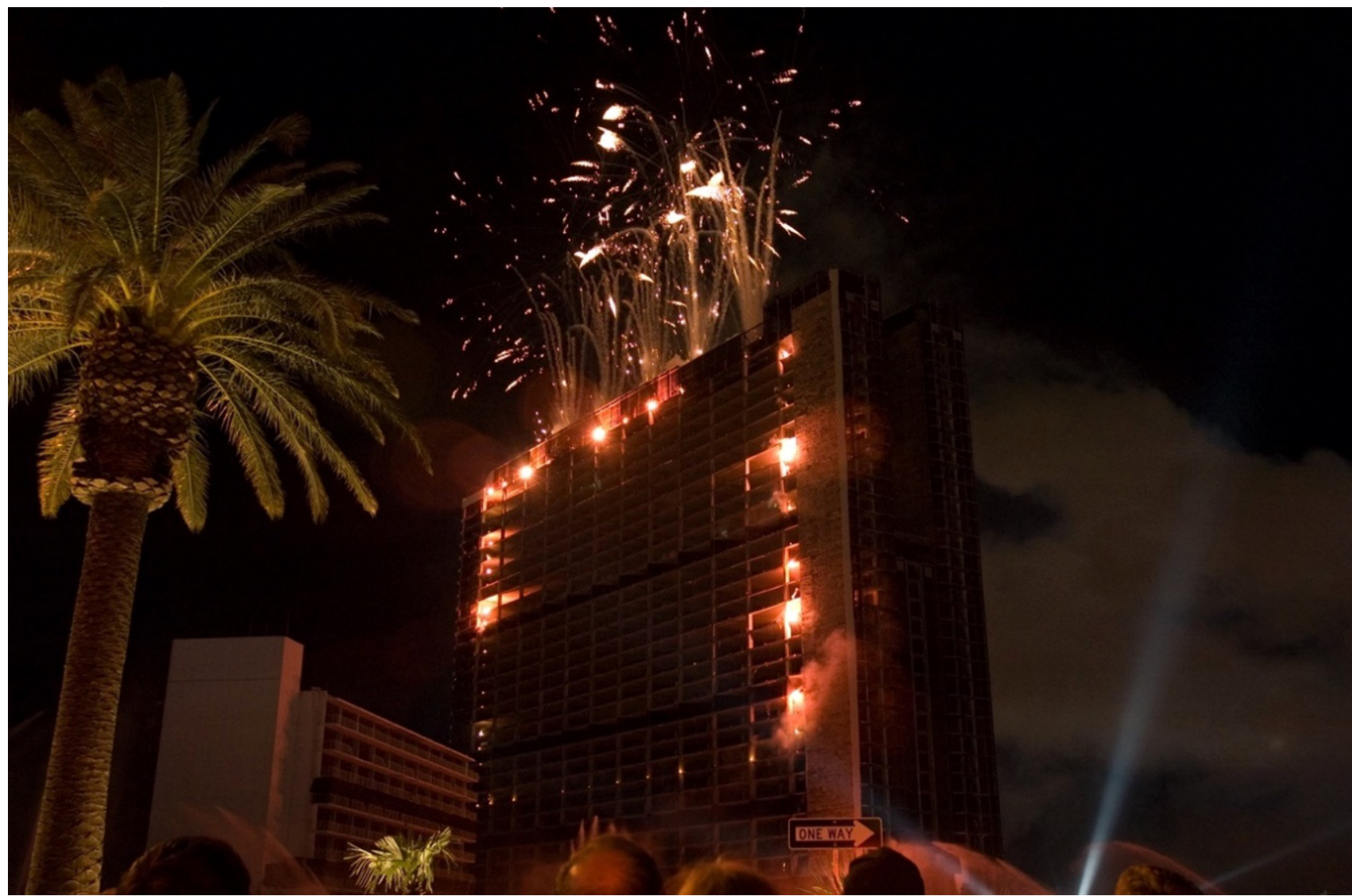

Figure 1. The spectacular night-time implosion of the famed Stardust casino-hotel-resort in 2007, complete with special lighting and fireworks. Source: Courtesy of Andrew Ferguson via Creative Commons.

At first glance, this phenomenon can be viewed as one that occurs "only in Las Vegas," as many observers have claimed about the city. However, such patterns of regular destruction and construction-while spectacular and occurring over compressed periods of time in Las Vegasoffer valuable insights into the nature of change in other contemporary cities as well, as I explain in the following sections.

A change in financing regimes from criminal mob to corporate mentality accelerated a particular aspect of capitalist development (Bernhard et al., 2008), which is the elimination of apparently old and tired products with newer and more profitable ones; that is, the building of larger casino-hotel-resort complexes. The scope of corporate wealth in the last several decades has meant that the city could offer a new level of extravagance and fantasy. Between 1993 and 2016, in a highly accelerated version of the fits-and-starts urban change that most American cities experience, Las Vegas demolished much of its recent history (Al, 2017; Rothman, 2003) with the implosion of 13 casinos, hotels, and resorts on the Strip: the Dunes, Landmark, Hacienda, Sands, Aladdin, El Rancho, Desert Inn, Boardwalk, Bourbon Street, New Frontier, Stardust, Clarion, and Riviera, and that were soon replaced by some of the new icons of the Strip, such as the Bellagio, Venetian, Mandalay Bay, Planet Hollywood, Wynn, and City Center (see Figures 2 and 3).
The owners of these privately owned casinos are powerful actors in the urban development process by any measure, especially financial ones. For example, in 1996 alone, banks lent an unprecedented amount of capital of $\$ 10$ billion to help corporations such as ITT Corporation, Circus Circus, Mirage, and MGM Grand expand their casinos (Al, 2017, p. 181). In another example in 2004, multibillionaire Kirk Kerkorian merged his MGM Mirage company with the Mandalay Resort Group to form the world's largest gambling company, until a few weeks later when Harrah's Entertainment bought Caesars Entertainment in a $\$ 9.25$ billion deal that created an even larger company (Stein, 2004, p. 24). Later the same year, Steve Wynn opened the $\$ 2.74$ billion Wynn Las Vegas hotel, casino, and resort. The manner in which Wynn Las Vegas exemplifies the fits-and-starts type of urban change is described in greater detail in Part 2 of the case study further below in the article.

A major reason for this continued influx of financing is that gambling had become a well-known enterprise and was already legal in 48 of the 50 states in the U.S. by the early 2000s. Furthermore, respected business leaders such as Terry Lanni, Glenn Schaeffer, and Gary Loveman had brought Wall Street credibility to an industry that needed it, and thereby allowed it to attract and spend unprecedented amounts of capital (Bernhard et al., 2008). Thus, a vision of capitalist development 


\begin{tabular}{|c|c|c|c|c|c|c|c|c|}
\hline Old Hotel Name & $\begin{array}{l}\text { Openin } \\
\text { g year }\end{array}$ & Number of Rooms & Original Owner(s) & Last Owner & Closing year & Demolition year & New Hotel Name & Number of Rooms \\
\hline Dunes & 1955 & 1200 & $\begin{array}{l}\text { Alfred Gottesman, Bob Rice and Joe } \\
\text { Sullivan [allegedly a frontman for Ray } \\
\text { Patriarca] - Dunes Hotels and Casinos } \\
\text { Inc. }\end{array}$ & $\begin{array}{l}\text { Mirage Resorts [Steve Wynn CEO] } \\
(1992)\end{array}$ & 1993 & 1993/1994 & Bellagio & 3005 \\
\hline Landmark & 1969 & 498 & Frank Caroll - Landmark Plaza Corp. & $\begin{array}{l}\text { Las Vegas Convention and Visitors } \\
\text { Authority (1993) }\end{array}$ & 1990 & 1995 & $\begin{array}{l}\text { Plot was turned into a } \\
\text { parking lot }\end{array}$ & \\
\hline Hacienda & 1956 & 1100 & Warren Bayleyand Judy Bayley & $\begin{array}{l}\text { Circus Circus Enterprises [Clyde } \\
\text { Turner CEO] (1995) }\end{array}$ & 1996 & 1996 & Mandalay Bay & 3211 \\
\hline Sands & 1952 & 720 & Jake Freedman and Jack Entratter & $\begin{array}{l}\text { Interface Group [Sheldon Adelson } \\
\text { CEO] (1988) }\end{array}$ & 1996 & 1996 & The Venetian & 3036 \\
\hline Aladdin & 1962 & 1100 & Edwin S. Lowe & $\begin{array}{l}\text { Sommer Family Trust [Jack Sommer } \\
\text { CEO] (1994) }\end{array}$ & 1997 & 1998 & $\begin{array}{l}\text { Aladdin (now called } \\
\text { Planet Hollywood } \\
\text { Casino and Resort) }\end{array}$ & 2600 \\
\hline El Rancho & 1948 & 1009 & Marion Hicks and Clifford A. Jones & $\begin{array}{l}\text { Turnberry Associates [Jeff Soffer } \\
\text { CEO] (2000) }\end{array}$ & 1992 & 2000 & $\begin{array}{l}\text { Drew Las Vegas } \\
\text { (unfinished) }\end{array}$ & 4000 \\
\hline Desert Inn & 1950 & 715 & Wilbur Clark with funding from Moe Dalitz & $\begin{array}{l}\text { Wynn Resorts [Steve Wynn CEO] } \\
(2000)\end{array}$ & 2000 & 2001 & $\begin{array}{l}\text { Wynn Las Vegas and } \\
\text { Encore }\end{array}$ & 2716 \\
\hline Boardwalk & 1966 & 650 & Holiday Inn & $\begin{array}{l}\text { MGM Mirage [Kirk Kerkorian CEO] } \\
\text { (1997) }\end{array}$ & 2006 & 2006 & $\begin{array}{l}\text { Waldorf Astoria at City } \\
\text { Center }\end{array}$ & 392 \\
\hline Bourbon Street & 1980 & 166 & John Harlow Tucker & $\begin{array}{l}\text { Harrah's Entertainment [Gary } \\
\text { Loveman CEO] (2005) }\end{array}$ & 2005 & 2006 & $\begin{array}{l}\text { Plot was turned into a } \\
\text { parking lot. }\end{array}$ & \\
\hline New Frontier & 1942 & 984 & R.E. Griffith and William Moore & $\begin{array}{l}\text { El-Ad Properties [Yitzhak Tshuva } \\
\text { CEO] (2007) }\end{array}$ & 2007 & 2007 & $\begin{array}{l}\text { Nothing has been built } \\
\text { yet. }\end{array}$ & \\
\hline Stardust & 1958 & 1065 & $\begin{array}{l}\text { Tony Cornero with funding from Moe } \\
\text { Dalitz }\end{array}$ & $\begin{array}{l}\text { Boyd Gaming [Sam Boyd and Bill } \\
\text { Boyd CEOs] (1985) }\end{array}$ & 2006 & 2007 & $\begin{array}{l}\text { Resorts World (under } \\
\text { construction) }\end{array}$ & 3500 \\
\hline Clarion & 1970 & 202 & Royal Inns of America & $\begin{array}{l}\text { Majestic Resorts [Lorenzo Doumani } \\
\text { CEO] (2014) }\end{array}$ & 2014 & 2015 & $\begin{array}{l}\text { Nothing new has been } \\
\text { developed yet. }\end{array}$ & \\
\hline Riviera & 1955 & 2075 & William Bischoff & $\begin{array}{l}\text { Las Vegas Convention and Visitors } \\
\text { Authority (2015) }\end{array}$ & 2015 & 2016 & $\begin{array}{l}\text { Part of the expansion of } \\
\text { the Las Vegas } \\
\text { Convention Center }\end{array}$ & \\
\hline
\end{tabular}

Figure 2. Fits-and-starts type of urban change occurs in a concentrated period of time: Table of 13 casinos, hotels, and resorts-and their hybrid complexes-demolished between 1993 and 2016 and replaced by new ones along the Las Vegas Strip. In terms of fits-and-starts type of change, it is interesting to note two phenomena in particular in this table: The relatively short time between the opening of the casino-hotel-casino and its demolition (e.g., only 35 years passed between the opening of the Dune in 1955 and its demolition in 1993) and the often vast differences in the original number of rooms and the number of hotel rooms in the new casino-hotel-resort (e.g., the original Sands had 720 rooms and its replacement the Venetian has 3,036 rooms-a more than four-fold increase). Note: In thoroughly conducting this research we found that a lot of existing scholarship about Las Vegas often repeats inaccurate facts and even indulges in popular myth-building. Therefore, to craft this table, we consulted 46 different reliable sources to check and cross-check these facts (for the full table and its many sources see Supplementary Material). Source: Courtesy of Juan Usubillaga, from multiple sources.

driven by corporate investors and private profit is embodied in such large-scale projects. Some historians trace the tipping point of the city from a mafia-dominated desert outpost to a corporate-driven entertainment destination to around 1988-1989 (Wood, 2005). This was when businessman Steve Wynn invested the unprecedented amount of $\$ 630$ million to build the copper-skinned ultracasino-hotel-resort called the Mirage. The Mirage created a model for clearing away old gambling hotels of the post-World War II era and replacing them with casinos the size of small castles on the Strip.

The graph below (see Figure 4) illustrates how an increase in hotel room inventory has actually induced demand rather than the other way around. In other words, new hotel-casino-resorts such as the Bellagio and Wynn Las Vegas were conceived not in response to the kind of market demand that conventional microeconomics and real estate development literature suggests, but rather the combination of manufactured obsolescence, future speculation, and generated marketing excitement (starting with highly publicized spectacular implosions) enticed more people to visit and stay in these developments. In fact, "the city has worked on the premise that supply breeds demand-build it, and they will come" (Pollack, 1997, para. 33). This counterintuitive approach sheds valuable light into what drives the fits-and-starts type of change not only in Las Vegas but also in other contemporary cities of capitalism. Of course, there are exceptions to this pattern, such as when there are financial or political crises or miscalculations that can lead to empty plots of land, land converted to parking lots, or half-finished structures.

\section{Case Study, Part 2: From the Desert Inn to Wynn Las Vegas}

The businessperson Wilbur Clark came from the city of San Diego in California to Las Vegas in 1944 and built what was originally called Wilbur Clark's Desert Inn, at the time the largest hotel in Las Vegas with 300 rooms and a three-story tower (see Figure 5). The casino-hotelresort opened on April 24, 1950, the fifth one on a two-lane highway that would later become the Las Vegas Strip, at a cost of $\$ 4.5$ million. On the first Saturday 


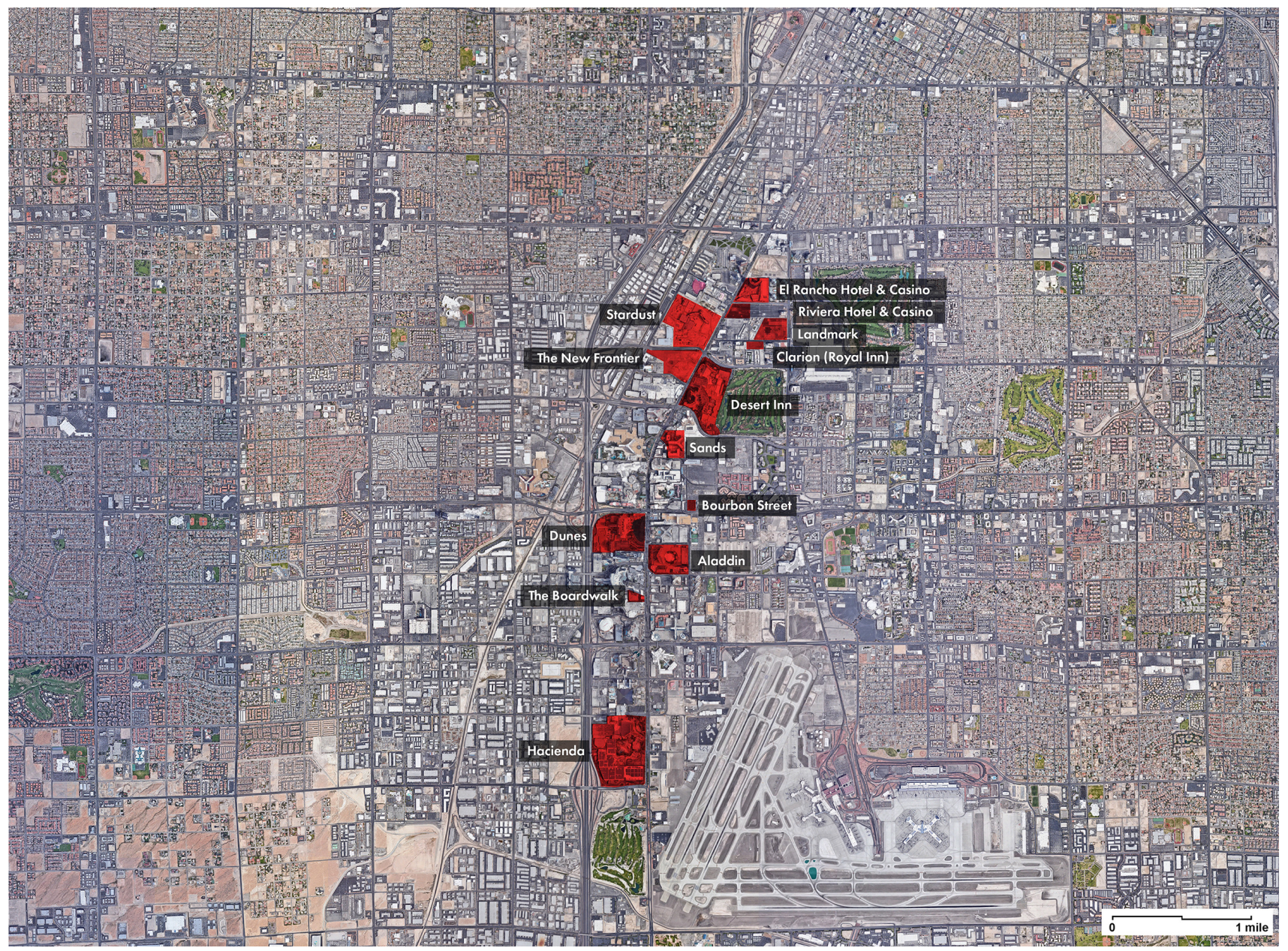

Figure 3. Fits-and-starts type of urban change also occurs in a concentrated amount of space: Aerial photograph of 13 casinos, hotels, and resorts-and their hybrid complexes-demolished between 1993 and 2016 and replaced by new ones along the Las Vegas Strip. Source: Courtesy of Juan Usubillaga, based on Google Earth, Google Maps, and historical archives in Special Collections of the University of Nevada Las Vegas Library.

Las Vegas Visitor Volume and Hotel Room Inventory 1970-2018

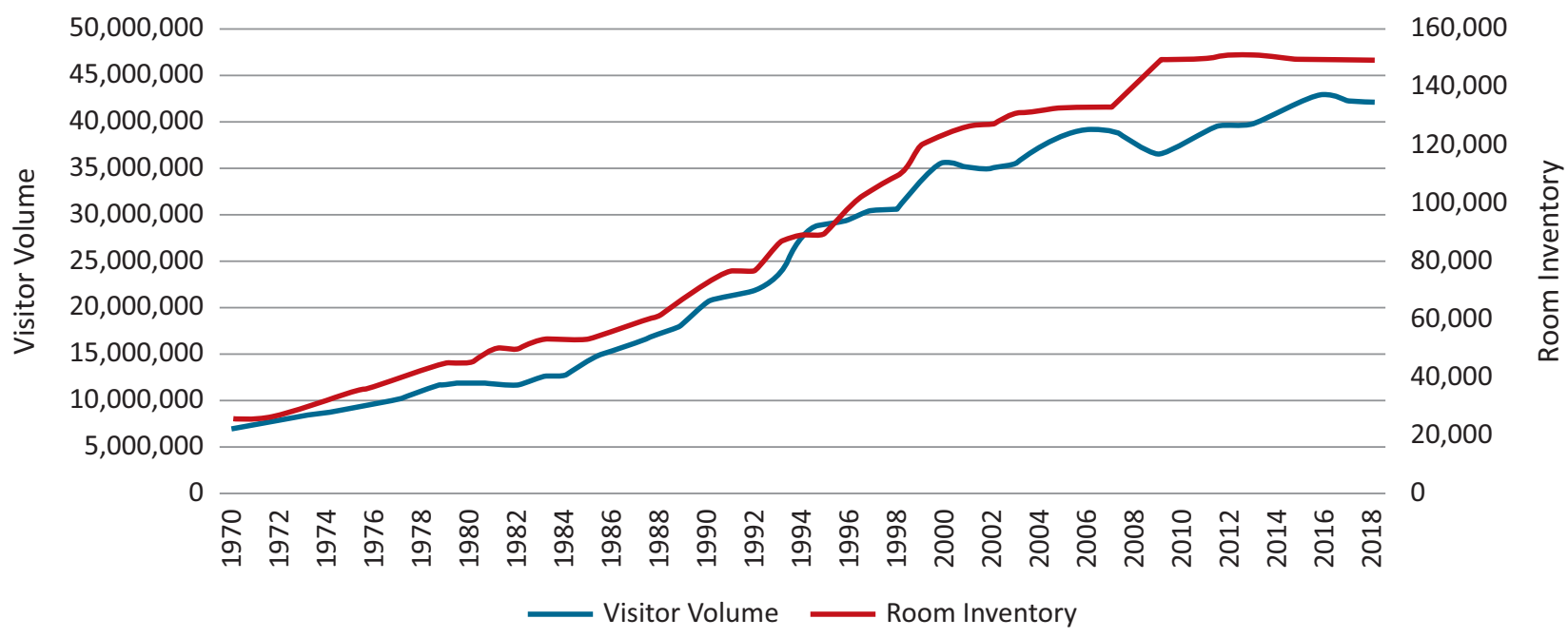

Figure 4. As this graph from the period 1970-2018 indicates, in Las Vegas visitor volume has tended to rise with hotel room inventory, pointing to induced demand. Source: Las Vegas Convention and Visitors Authority Research Center (2018). 
after the opening, the Desert Inn casino lost $\$ 87,000$ in one eight-hour shift, including $\$ 36,000$ to one lucky winner, but it was the best publicity any casino-hotel-resort could ask for. People flocked to the Desert Inn, and by the following Friday, the casino had recouped its losses, with the first week's profits totaling $\$ 750,000$ (Russo, 2006, p. 207).

By 1963, the Desert Inn became part of the trend to expand hotels, with a total of more than 5,000 rooms added in the city, which was at the time "the largest, fastest, most concentrated sustained expansion of its kind anywhere in the world" (Denton \& Morris, 2001, p. 226). The well-known billionaire Howard Hughes, who in November 1966 rented all of the resort's ninth-floor penthouse suites, bought the Desert Inn in 1967 for \$13.25 million after its then-owner and well-known affiliate of the mafia, Moe Dalitz, tried to kick Hughes out because he needed the hotel rooms to accommodate several other wealthy and high-profile gamblers. Hughes's purchase of the Desert Inn laid the precedent for the later corporate era of Las Vegas casino-hotelresorts by subsequently by other properties such as the Sands, Castaways, Silver Slipper, and Frontier ("Desert Inn chronology," 2005).

In 1988, millionaire Kirk Kerkorian acquired the Desert Inn and operated it for five years before selling it to ITT Corporation. Starwood Hotels and Resorts then acquired the Desert Inn in 1998 when it bought ITT Corporation. However, Starwood Chairman Barry
Sternlicht immediately put the Desert Inn on the auction block because, despite a recent $\$ 200$ million renovation, it was losing money and the company needed the money to pay down debt, strengthen its balance sheet and reinvest in existing assets (Thompson, 1999). In 1999, Sun International Hotels bought the development from Starwood Hotels \& Resorts for \$275 million cash and company chairman Sol Kerzner hinted already that they had plans a major development on that property (Thompson, 1999).

The next year, Steve Wynn purchased the Desert Inn for \$270 million (see Figure 6) supposedly as a birthday gift for his wife, Elaine ("Desert Inn chronology," 2005). Almost immediately, Wynn began a campaign for manufacturing its obsolescence in order to demolish it: "The present [Desert Inn] is too small, too close to the street, it's right up against the sidewalk, there's no room for cabs," he said, adding that "it's a thing from the 50s" and "it's not a competitive facility" ("Wynn plans new Strip resort," 2000, para. 14). Furthermore, he said he could not:

Protect the employees from the lamination of mistakes that have been made since 35 years ago when Moe Dalitz sold this place....It seems that every time one of the owners stepped up to fix it, they lost their focus, did everything but the right thing.....Nothing at the Desert Inn has been the way it should be. ("Wynn tells all," 2000, para. 34)

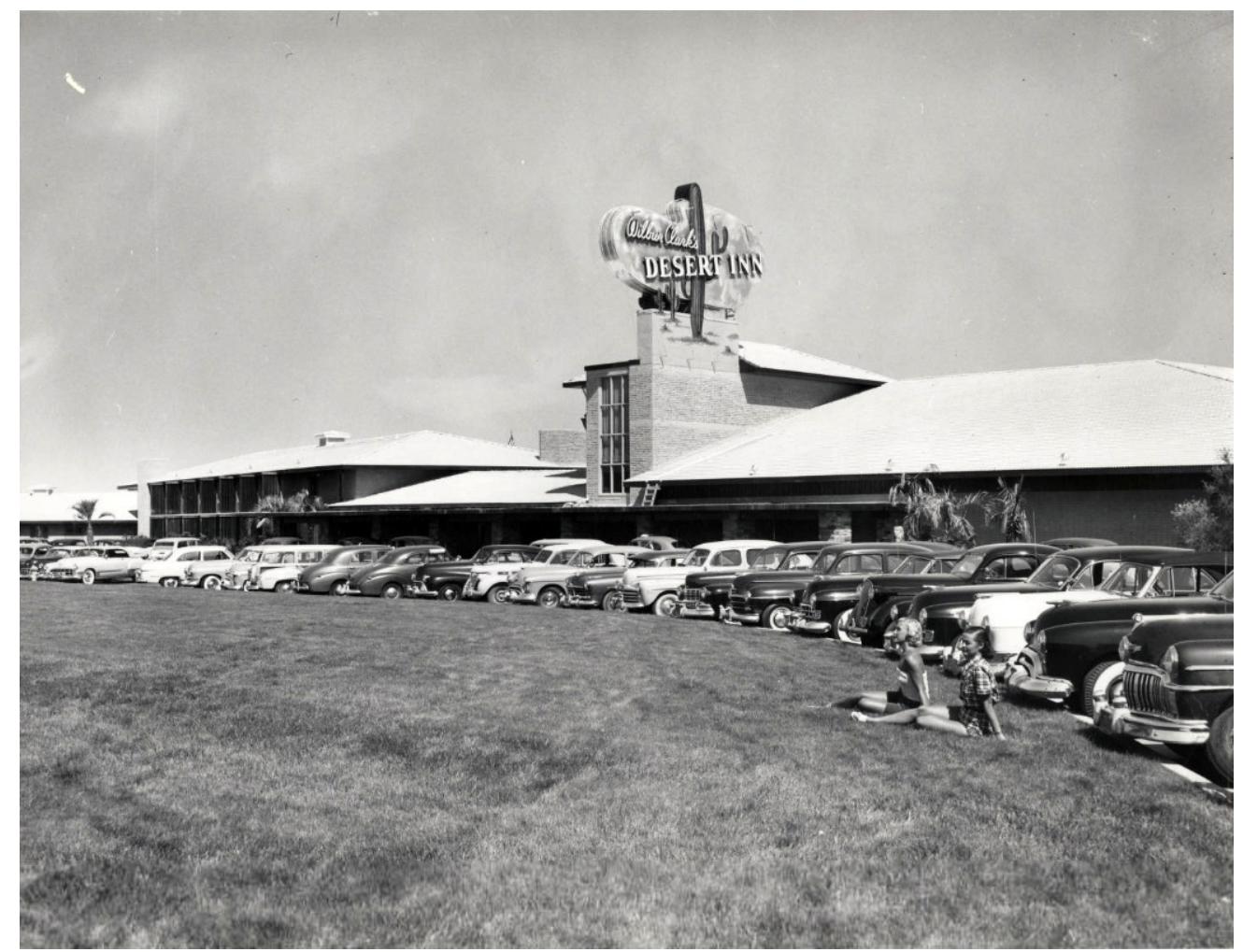

Figure 5. The original Desert Inn, seen from the front in this image from the 1950s, was pioneering in terms of its size and layout as a casino-resort-hotel on the automobile-oriented Las Vegas Strip. Source: "Photograph of the front of Wilbur Clark's Desert Inn" [ca. 1950s]. 


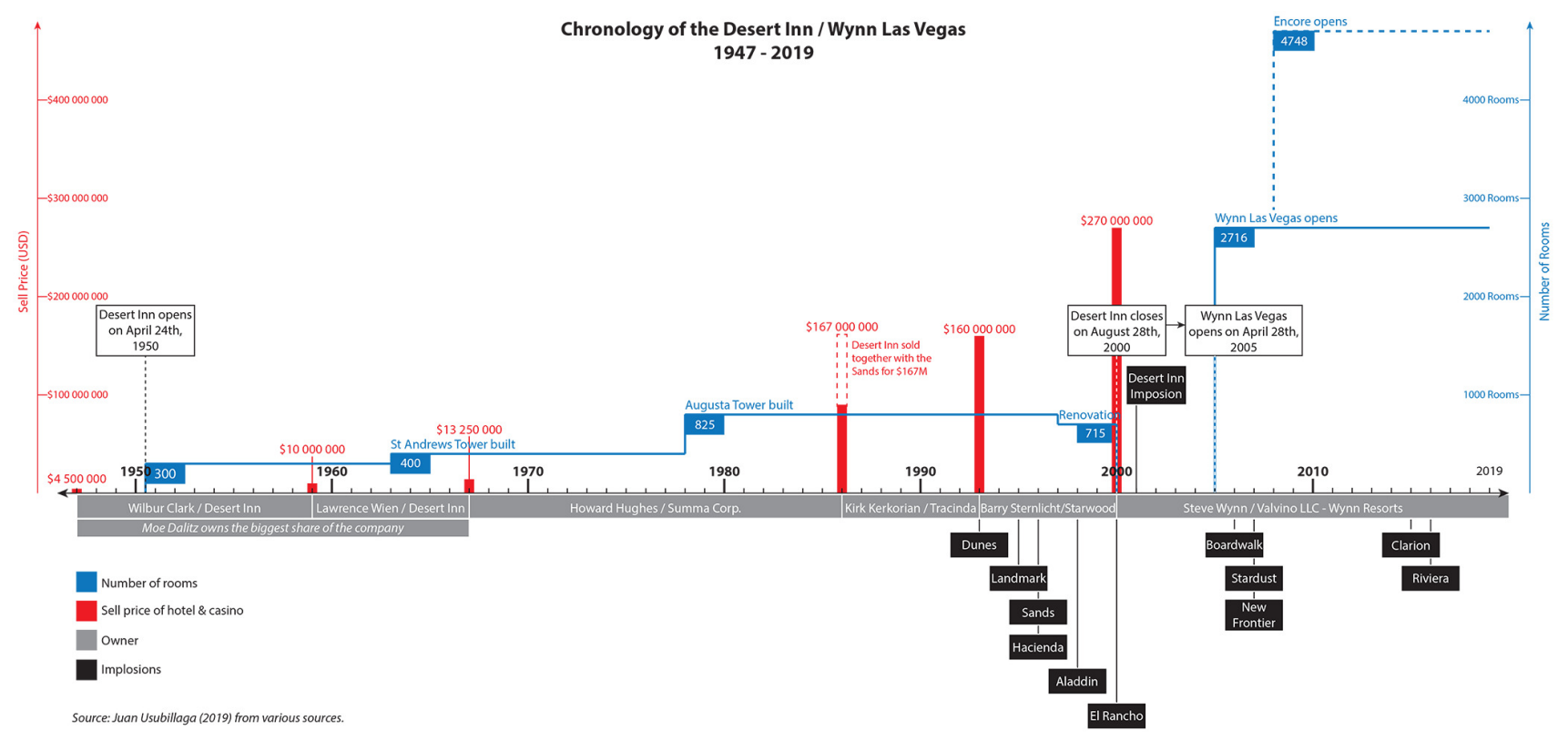

Figure 6. Fits-and-starts at a micro-scale: Desert Inn/Wynn Las Vegas timeline, with the key events being the closing of the Desert Inn in 2000 and the opening of the much larger and much more complex Wynn Las Vegas only five years later in 2005. Source: Courtesy of Juan Usubillaga, based on "Desert Inn chronology" (2005) and Wynn Resorts Limited (2003-2019).

While manufacturing the Desert Inn's obsolescence, Wynn simultaneously began a campaign of future speculation to attract investors, saying that the new development on the Desert Inn site would cause a "shift in the center of gravity from where it's been" and that the resort would naturally have walk-in traffic because of "a little, old pirate gimmick" at the Treasure Island, which was not far from his property line and which drew thousands of gawkers a day ("Wynn tells all," 2000, para. 37). Indeed, in acquiring the Desert Inn he had purchased one of the largest available land parcels on the Strip, with seemingly unlimited potential for new development by claiming that it was "the most powerful piece of real estate in Nevada, possibly in the western United States," and that it was "an extraordinary piece of property, with the opportunity to do just about anything" (Strow, 2000, para. 2). He made sure to highlight other property's advantages, such as rights to huge amounts of water under the land, frontage on the famed Las Vegas Strip, as well as on to major arterial roads such as Paradise Road, Sands Avenue, and Desert Inn Road, and easy access to both the Las Vegas Convention Center and the Sands Expo Center.

Wynn already began financing the project as he was making these public statements (Wynn Resorts Limited, 2003-2019). For example, in April 2000, a new company called Valvino LLC was formed with Wynn being the only shareholder and a \$221 million equity contribution by him. Subsequently, in June 2000, Valvino LLC bought the Desert Inn for $\$ 270$ million, while the next month, Deutsche Bank loaned \$125 million to the company. The Desert Inn closed on August 28, 2000, and in October 2000, Aruze USA-the U.S. subsidiary of a Japanese manufacturer of gambling and arcade machines-contributed \$260 million and obtained 50\% membership of Valvino LLC. In the process, the Deutsche Bank load was repaid. This is just a snippet of the multiple financing arrangements early in the process, but given the ultimate cost of the new and highly ambitious project, much more funding had to be raised (see Figure 7). So, he then embarked on a grueling two-week road show in October 2002 to pitch Wynn Resorts Limited to major institutional investors. He requested one-and-a-half-hour meetings with fund managers who were accustomed to a one-hour time limit. He did every presentation himself and handed out his cellphone number to fund managers (Binkley, 2018, p. 213). His fundraising and speculation about future profits began to pay off early in the process because with no properties open and no revenues, Wynn Resorts stock was trading on pure speculation. It shot up from its initial offering price of $\$ 13$ in October 2002 to $\$ 76.45$ a share on March 16, 2005: "[As a result,] Wynn was [now] a billionaire" (Binkley, 2018, p. 249).

The brand new Wynn Las Vegas casino-hotel-resort opened on April 28, 2005, at the cost of approximately $\$ 2.74$ billion (i.e., more than 10 times the price of the purchase of the Desert Inn and its land) and with 9,000 employees (Wynn Resorts Limited, 2003-2019). The extremely high cost was due to its sheer size and amenities geared towards clients with higher disposable incomes. The Wynn Las Vegas included a casino of 111,000 square feet in floor space and 137 table games, 2,674 hotel rooms in a 45 -story tower plus 36 separate villas (see Figure 8), a resort consisting of six restaurants, nightclub, spa and salon, Ferrari and Maserati dealership, wedding chapels, 18 -hole golf course, 223,000 square feet of meeting spaces, 76,000 square feet of retail, 


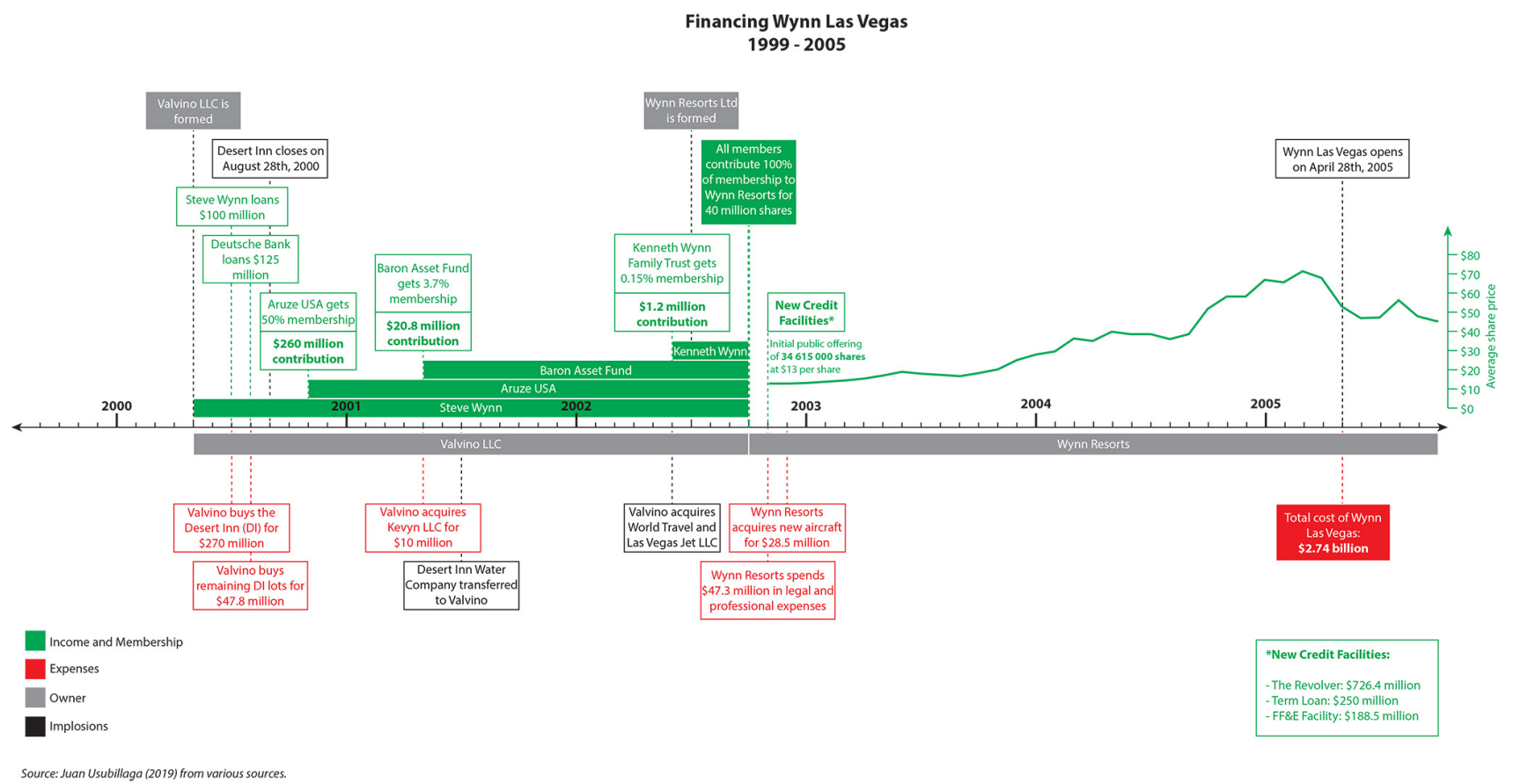

Figure 7. Financing fits-and-starts type of urban change can be complex, time-consuming, and frequently requires multiple sources: Timeline of financing the new \$2.74 billion Wynn Las Vegas casino-hotel-resort. Source: Courtesy of Juan Usubillaga, based on Wynn Resorts Limited (2003-2019).

and two theatres, Wynn Theater and Broadway Theater, which opened later in August 2005 (see Figure 9).

During this process, Steve Wynn also rethought the quality and standards of design from a gambling industry perspective:

Our challenge was to surpass the standards we had worked so hard to set [previously] at the Bellagio. You really can't just do another Bellagio. Is there another level? For that reason we had to go back to very primary ideas. We had to reexamine the most fundamental issues that have to do with design. ("Mr. Las Vegas," 2008, p. 57)

The combined approach of sheer size, mix of facilities, and raising the design standards seemed to pay off a few months after Wynn Las Vegas opened. For example, already in 2005, the casino-hotel-resort's average hotel room occupancy was $92.1 \%$ as compared to the average of $89.2 \%$ on the Las Vegas Strip, the average daily hotel room rate was $\$ 274$ compared to the average of $\$ 103$ on the Strip, and the net revenue for the year was $\$ 722$ million, with $49 \%$ of it coming from gambling activities and $51 \%$ from hotel and resort facilities (Wynn Resorts Limited, 2003-2019).

The high hotel room occupancy rates and the equally impressive net revenue for the Wynn Las Vegas in its very first year was due to the creation of a buzz through word of mouth by Steve Wynn and extensive marketing by his company. There was another contributing factor, which was the broader trends in Las Vegas that year. As seen in the graph below (see Figure 10), in 2005, the
Las Vegas gambling and hotel markets continued their upward trends with, among other things, a 3.2\% increase in visitation, a $13.1 \%$ increase in Strip gaming revenue, a $1.3 \%$ increase in hotel room inventory, and a $14.9 \%$ increase in average daily room rates, as compared to 2004 (Wynn Resorts Limited, 2003-2019).

The implosion of the old Desert Inn and the construction of the new Wynn Las Vegas was not only part of this period of fits-and-starts urban change in the city, but also had longer-term ripple effects. In fact, Steve Wynn had planned a $\$ 500$ million expansion, with construction on a second tower to build on Wynn Las Vegas's momentum. With an additional 1,300 hotel rooms, he predicted that it would add to his profits, because as fellow casino-owner Glenn Schaeffer suggested, hotel rooms had replaced slot machines as the market's most powerful revenue driver: "Strip operators have twice as many rooms as slots," he said ("Second tower planned," 2004, para. 11). Ron Kramer, then-president of Wynn Resorts Limited, had also realized that a recent refinancing of the company was so popular with investors and banks that money was available for additional spending on the Las Vegas site ("Desert Inn chronology," 2005). The construction of Encore began in 2006 and it opened in 2008. This illustrates how speculation about future profit is an ongoing process rather than being satiated by a singular project.

Like many business owners, property investors and real estate developers, Wynn was involved in many projects in the city, including the demolition of old casinos and the construction of new and trend-setting casino-hotel-resorts such as the Mirage in 1989 and the 


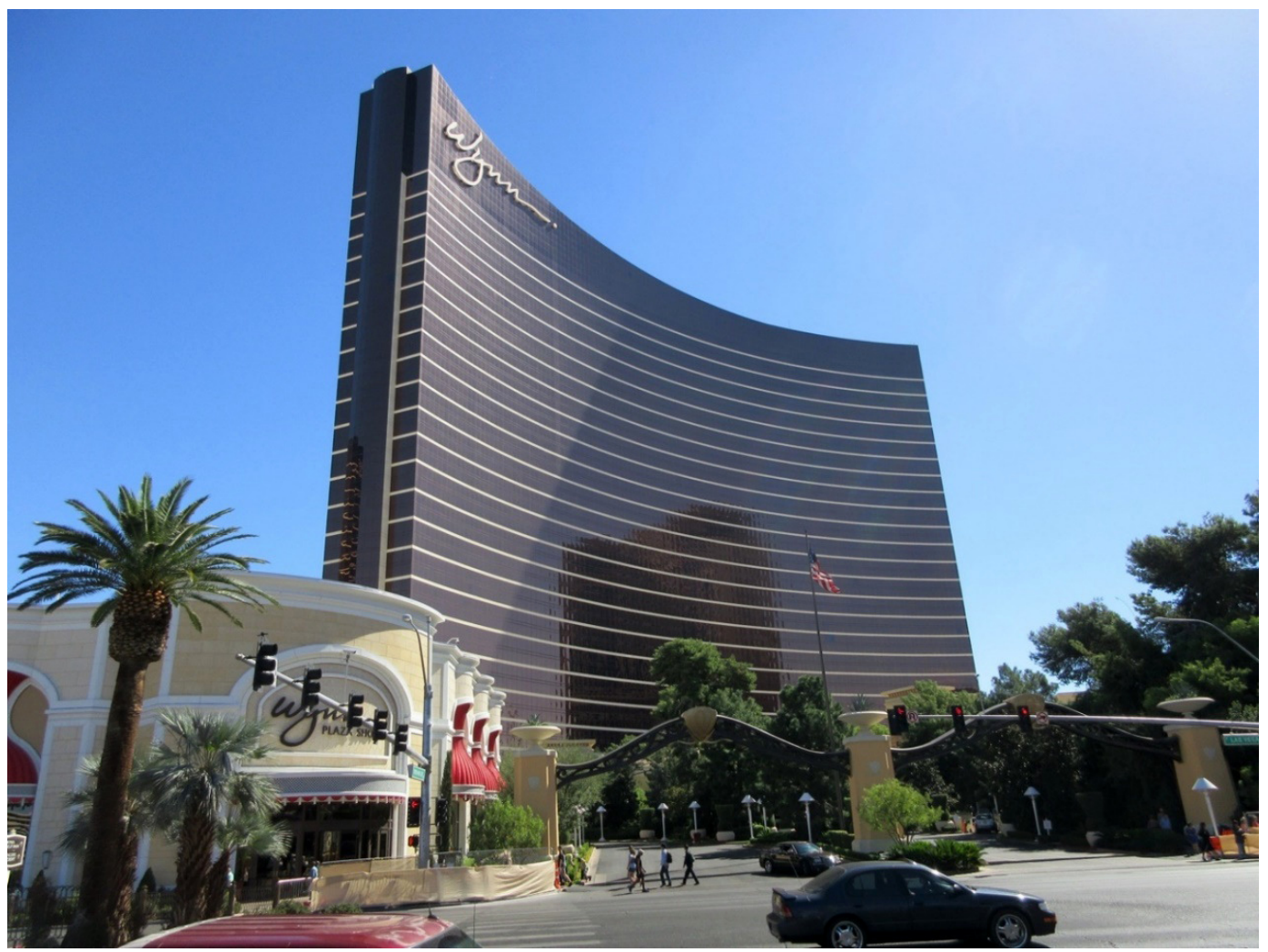

Figure 8. View of the front of the Wynn Las Vegas. Compare the size and style of its design with the Desert Inn in Figure 5. Source: Aseem Inam.

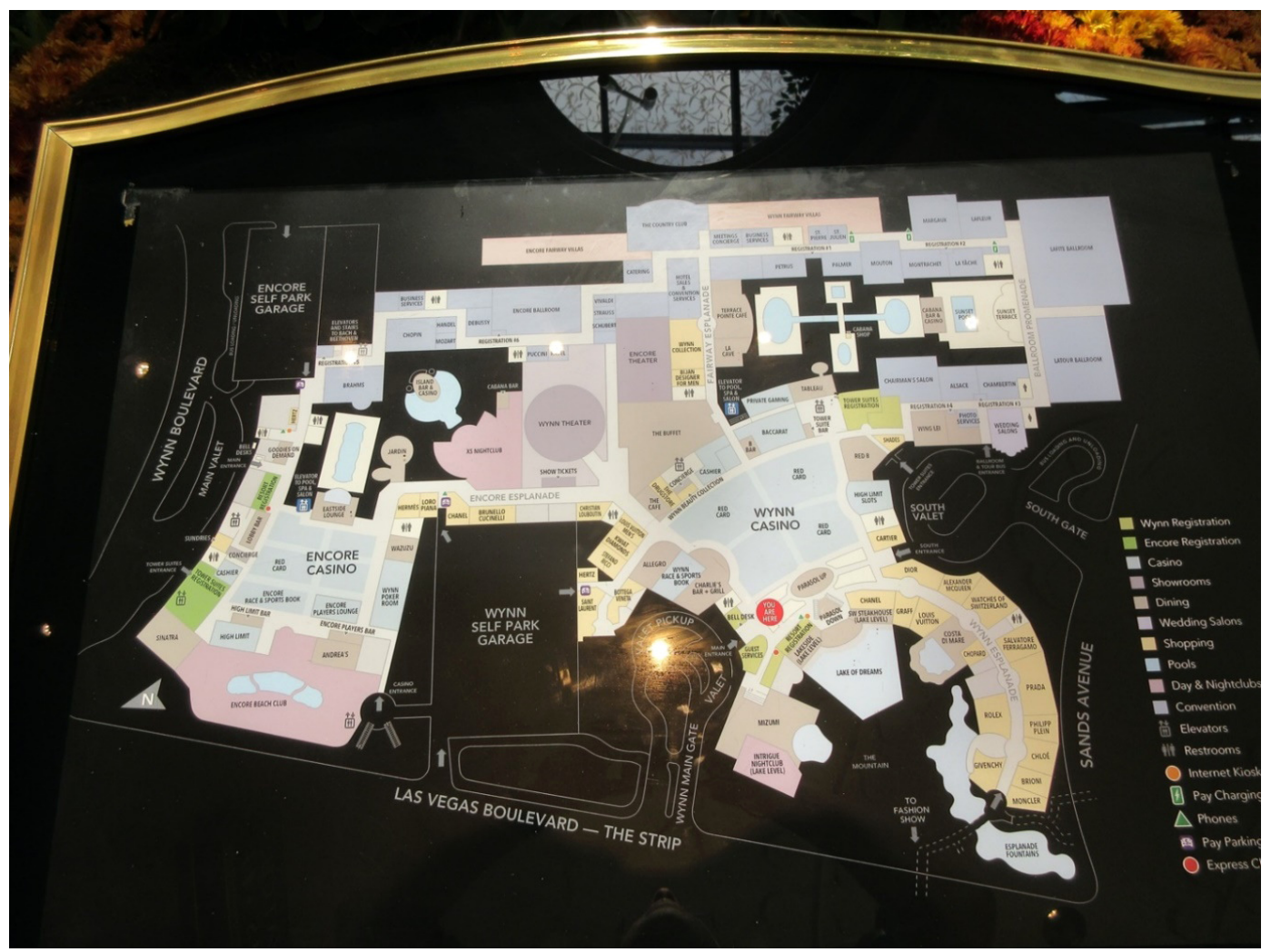

Figure 9. The full size and complexity of the facilities of Wynn Las Vegas casino-hotel-resort (along with its subsequent twin, Encore) can be grasped via this floor plan. Source: Aseem Inam. 


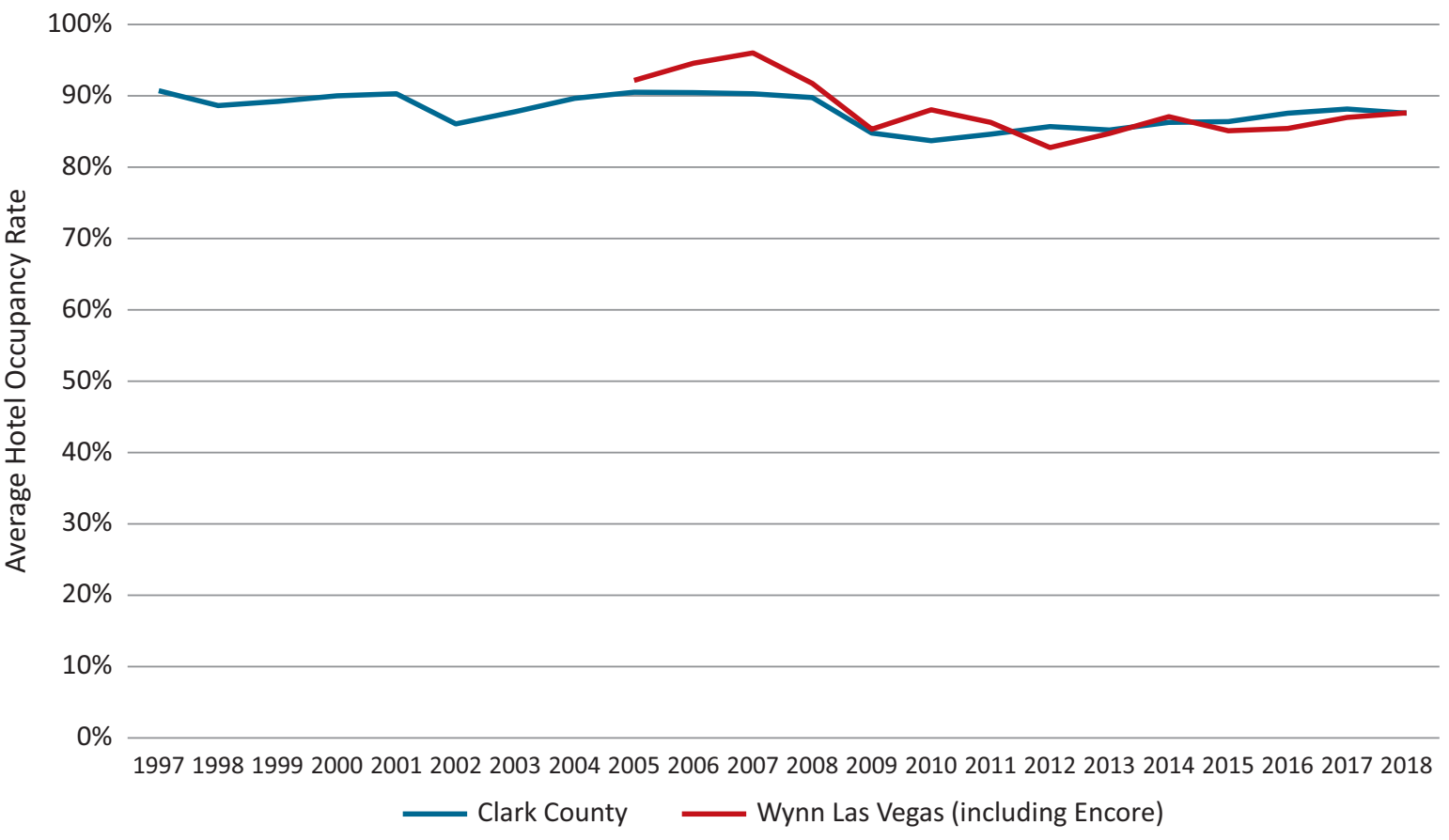

Figure 10. Average hotel occupancy rates in Wynn Las Vegas, compared to average in Clark County (for hotels with gambling revenue of \$1 million and over). Sources: Nevada State Gaming Control Board (1997-2018) and Wynn Resorts Limited (2003-2019).

Bellagio in 1998, which involved the implosion of the old Dunes (see Figure 2). Long-time observers of the city acknowledge the role he has played by saying that he had been a prominent and visible Las Vegas gambling industry leader, who not only represented the current era but was also connected with the city's previous eras. For example, the "dream that Wynn realized at the Mirage in 1989 stands as the most important development in Las Vegas in the past twenty years" (Bernhard et al., 2008, p. 183). As happens to long-time business people with a public presence who help drive fits-and-starts type of urban change, there is also a bit of myth-building about them, which then influences how financial analysts and funding institutions perceive them, and which subsequently eases their ability to attract investors for their projects: "Whatever he builds, it will be one up on the last thing he built... it's really exciting for Las Vegas to continue that legacy of creation," said David Atwell, a local casino-hotel-resort broker (Strow, 2000, para. 16), while for Prudential Securities financial analyst Joe Coccimiglio, "[Wynn] tends to build properties that create more [demand] than they can supply" (Strow, 2000, para. 22). Such myth-building is helpful for not only branding purposes but also higher profitability. For example, Frank Luntz, a pollster who had been doing marketing polls for Wynn for years, ran focus groups on the new resort's name and discovered that Wynn's name alone was worth an extra $\$ 80$ per night for a hotel room. He recommended naming the casino after its developer
(Binkley, 2018, p. 241). Wynn followed the advice and reaped its rewards.

\section{Conclusion: Insights and Implications}

In the material city, fits-and-starts type of urban change creates interruptions and disruptions in the time and space of what might otherwise be thought of as more long-term and slow-moving urbanism. Such change, concentrated in space and time as it is, nonetheless has larger-scale and longer-term impacts not only on those particular parcels of land but also on the surrounding area. While urban practitioners tend to be biased towards continual growth of the city, which implies something new will always replace something old, these patterns of change also reveal that the intended outcomes does not necessarily materialize (e.g., due to financial crises, lack of market demand, problems with construction, and a myriad of other problems). In these processes, what matters are human perceptions and beliefs, including and especially the perceived economic value of an existing building versus the belief in the higher profitability of a newer building. I have adopted an agent-centered approach by focusing on primary decision-makers in such contexts, who are private developers, property owners, and investors. As the Las Vegas case illuminates, it is often large-scale owners and developers who radically reimagine the material city in terms of urban form and space and harness the resources to 
extract value from opportunities that few others may perceive. In this manner, the spatial production and reproduction of the city is significantly influenced by the ability of these key actors to buy and sell land, raise and borrow the funds, assemble a team of specialists, realize their vision, and in the process enhance the value of property, which is the bedrock of the capitalist city in the late 20th and early 21 st centuries, or, as some authors prefer to call them, "cities of capitalism" (e.g., Stevenson, 2012). I have described a particular kind of fits-and-starts type of urban change driven by the thinking of people like Wynn and his company.

What emerges from this analysis of the literature as well as of the case study are two interrelated ideas, that of manufactured obsolescence and of future speculation, which help drive fits-and-starts type of urban change. In Las Vegas and most other cities in the capitalist system, obsolescence is the state of being which occurs when an object such as a building or a public space or a piece of infrastructure in a city, service, or practice is no longer deemed desirable even though it may still be in good working order. Obsolescence frequently occurs when a replacement has become available that is perceived to possess more advantages compared to the disadvantages incurred by maintaining or repairing the original (Weber, 2002). Manufactured obsolescence occurs when a building is only a few decades old and is structurally and functionally sound, but is made to appear outdated and unsatisfactory for present and future needs. The idea of manufactured obsolescence, usually promoted by real estate agents, private investors, property owners and real estate developers, is to diminish-often radically - the current economic (and sometimes social and even political) value of a current structure or space in order to promote a newer and supposedly better replacement.

Future speculation is not only a corollary of manufactured obsolescence, but also what often pushes for such type of obsolescence in the first place. Future speculation in real estate development is about formulating expectations about the future return on investment based on location, type, and timing of development. While real estate and economics textbooks may highlight the need for formal market analysis in order to gauge demand (e.g., Peiser \& Hamilton, 2012), the reality is more muddy, including projects in urbanism that actually create demand where there was no clear a priori evidence of it (e.g., in the U.S., the success of the New Urbanism movement comes to mind) or when an investor or developer bases multimillion dollar decisions on hunches, which are of course informed by knowledge and experience (e.g., Steve Wynn, or as our research has previously documented in Inam et al., 2004). Thus, the material city is a world of things (e.g., buildings and larger scale complexes) that are commodities in which investors take a financial risk with various degrees of calculations and estimations about future return on investment (i.e., profit). Such perceptions and pursuits of future profit are aided and abetted by an arms race for one-upmanship through informal conventions of not only casino owners but those who are integral to the real estate development industry, including financiers, brokers, and designers such as architects, interior designers, and landscape architects. Local governments also function as facilitators of fits-and-starts type of urban change, including in some cases by adopting more of an actively laissez-faire attitude (as in Las Vegas, which includes bending over backwards to accommodate almost any kind of novelty), or in other cities, a more actively supportive role. Governments welcome such types of speculative urbanism because to them new construction symbolizes progress, generates new tax revenue, and creates new economic activity such as jobs.

However, fits-and-starts type of urban change, as embodied in demolition/construction booms, has enormous economic, social, and environmental costs, for example by demolishing entire parts of a city and building large new buildings and complexes. Reusing existing space is the more fiscally, economically, and environmentally sound approach to managing urban change, one that can accommodate growth and innovation while also valuing attachments to the artifacts and landscapes of the past. Lynch (1972) noted that places that grow slowly are often richer, more complex environments with choices and services better suited to the plurality of needs and values of a diverse population. Such places tend to grow in a deliberate manner that values quality of life, the preservation of difference and environment, and place attachment based on emotions and memory. Moreover, building a new structure when an existing one would have served the same purpose can be wasteful. Construction consumes tremendous amounts of natural resources and energy; gypsum is mined in the U.S. for drywall, forest products are harvested in Canada, and China provides U.S. contractors with tons of stainless steel (Weber, 2015). As raw materials and finished products are being harvested and manufactured in increasingly far away locales, they must be shipped longer distances, depending on the locations of their points of origin and consumption. Long-distance trips increase fossil fuel use and carbon emissions and also raise prices for consumers. The construction process itself creates great quantities of waste, which localities must process, dump or export. The bulk of local waste streams is comprised of materials produced by building activity; approximately 160 million tons of construction and demolition debris is generated in the U.S. every year (Weber, 2015). These materials include scrap lumber and other wood products, brick and block, gypsum wallboard, manufactured wood, asphalt shingles and pavement, metals, plastics, concrete, and dirt, as well as salvageable appliances, ornaments, and fixtures. An estimated $60 \%$ of the total volume of construction and demolition debris is sent to landfills, where it increases the level of spatially concentrated toxins that may leak into the ground or become airborne emissions. 
I now conclude with two implications of this analysis for urban practice. First, urbanists-particularly those with backgrounds in professional fields like architecture, landscape architecture, urban design, and city planning-have traditionally been trained to view the city as an object that is planned, designed, and built according to definitive visions. While urban geographers and historians have studied change for quite a while, such thinking has not yet fully permeated the world of mainstream practice in a meaningful manner. What would be the benefits if urbanism, both as an object of study and as a mode of practice, were to be approached from the perspective of flux rather than just an object? A significant implication of this discussion for urban practice is that those who work towards urban transformation require a concept of the city as flux as ongoing processes and changes, a stream of interactions, and a flow of situated initiatives (Inam, 2014). One way to ground this concept is with urban practices that accommodate and experiment with everyday contingencies, breakdowns, exceptions, opportunities, and unintended consequences that are encountered. Overall, the point is for urbanists to actively conceptualize and continually engage with cities as flux in addition to their threedimensional materiality. The challenge in getting to this point is two-fold: first, how to reconcile it with a basic human need and indeed, desire, to perceive stability in our worlds, and second, to reconcile the urbanists' need, and stemming often from their design training, to view interventions in primarily fixed, material terms.

Second, there are implications of this analysis in terms of new types of urban practices. Las Vegas has examples of more equitable and democratic types of urban practice that is one potent model for transforming urbanism, such as the active role of labor unions in a city's spatial political economy. However, in the context of this particular analysis, the idea of degrowth holds much promise. The idea of degrowth has been around formally since the Buddhist ethics of economics first practiced by the Emperor Ashoka in the 3rd century BC in India and the anti-industrialist trends in the writings of John Ruskin, Henry David Thoreau, and Leo Tolstoy in the 19th century in the Global North. In the late 20th and early 21st centuries, degrowth has come to mean reducing excess resources and energy throughput from the perspective of ecology while at the same time improving human well-being and social outcomes. Currently, the economic imperative-including in urbanism-is the often implicit assumption that growth is good, while in a degrowth scenario, the goal would be to scale down ecologically destructive and less socially necessary production while enhancing parts of the economy devoted to human well-being and ecological enhancement. More recently, there has been an increasing interest in the relationship between degrowth and urbanism (e.g., Savini, 2021; Xue, 2021), including new spatial strategies and social transformations that challenge the ideology of land scarcity and territorial economic competition which are often embodied in the fits-and-starts types of urban change. Such types of urban practices possess much promise for mitigating the high costs of fits-and-starts type of urban change.

\section{Acknowledgments}

The author would like to acknowledge the valuable research assistance of Juan Usubillaga and the financial support of the Welsh School of Architecture at Cardiff University. The author also acknowledges the helpful comments of three anonymous reviewers, as well as the support of the editors and staff of the Urban Planning journal, especially Tiago Cardoso.

\section{Conflict of Interests}

The author declares no conflict of interests.

\section{Supplementary Material}

Supplementary material for this article is available online in the format provided by the author (unedited).

\section{References}

Al, S. (2017). The Strip: Las Vegas and the architecture of the American dream. MIT Press.

Beauregard, R. (1990). Bringing the city back in. Journal of the American Planning Association, 56(2), 210-215.

Berman, M. (1982). All that is solid melts into air: The experience of modernity. Simon and Schuster.

Bernhard, B., Green, M., \& Lucas, A. (2008). From maverick to mafia to MBA: Gaming industry leadership in Las Vegas from 1931 through 2007. Cornell Hospitality Quarterly, 49(2), 177-190.

Binkley, C. (2018). Winner takes all: How casino Mmogul Steve Wynn won-and lost-the high stakes gamble to own Las Vegas. Hachette Books.

Byles, J. (2005). Rubble: Unearthing the history of demolition. Harmony Books.

Denton, S., \& Morris, R. (2001). The money and the power: The making of Las Vegas and its hold on America. Vintage Books.

Desert Inn chronology. (2005, April 28). Las Vegas Sun. https://lasvegassun.com/news/2005/apr/28/ desert-inn-chronology

Feagin, J. (1982). Urban real estate speculation in the United States: Implications for social science and urban planning. International Journal of Urban and Regional Research, 6(1), 35-60.

Feagin, J., \& Parker, P. (1990). Developers, bankers, and speculators. In R. Parker (Ed.), Building American cities: The urban real estate game (pp. 63-92). Prentice Hall.

Fletcher, R. (2012). Urban materialities: Meaning, magnitude, friction, and outcomes. In D. Hicks 
\& M. C. Beaudry (Eds.), The Oxford handbook of material culture studies. Oxford University Press. https://www.oxfordhandbooks.com/view/10.1093/ oxfordhb/9780199218714.001.0001/oxfordhb9780199218714-e-20?rskey=oRjEzv\&result=1

Flyvbjerg, B. (2006). Five misunderstandings about casestudy research. Qualitative Inquiry, 12(2), 219-245.

Geddes, P. (1915). Cities in evolution: An introduction to the town planning movement and to the study of civics. Williams.

Hack, G. (2011). Urban flux. In T. Banerjee \& A. Loukaitou-Sideris (Eds.), Companion to urban design (pp. 446-462). Routledge.

Harvey, D. (1978). The urban process under capitalism: A framework for analysis. International Journal of Urban and Regional Research, 2(1), 101-131.

Harvey, D. (1990). The condition of postmodernity. Wiley. Harvey, D. (1991). The condition of postmodernity: An enquiry into the origins of cultural change. Wiley.

Inam, A. (2012). From intentions to consequences: San Diego TOD design guidelines and Rio Vista West project. Urban Design and Preservation Division, American Planning Association.

Inam, A. (2014). Designing urban transformation. Routledge.

Inam, A. (2016). Unveiling Vegas: Urbanism at the nexus of private profit and public policy. Journal of Urbanism: International Research on Placemaking and Sustainability, 9(3), 216-236.

Inam, A., Levine, J., \& Werbel, A. (2004). Production of alternative development in American suburbs: Two case studies. Planning Practice and Research, 19(12), 211-217.

Koolhaas, R. (1978). Delirious New York: A retroactive manifesto for Manhattan. Oxford University Press.

Kostof, S. (1999). The city assembled: The elements of urban form through history. Bulfinch Press.

Las Vegas Convention and Visitors Authority Research Center. (2018). LVCVA executive summary of southern Nevada tourism indicators: Year-end summary for 2018. https://www.lvcva.com/research/visitorstatistics

Levine, J., \& Inam, A. (2004). The market for transportation-land use integration: Do developers want smarter growth than regulations allow? Transportation, 31, 409-427.

Lieto, L. (2017). How material objects become urban things? City, 21(5), 568-579.

Lynch, K. (1972). What time is this place? MIT Press.

Malpezzi, S., \& Wachter, S. (2005). The role of speculation in real estate cycles. Journal of Real Estate Literature, 13(2), 143-164.

Mr. Las Vegas. (2008, June 1). Lodging Hospitality.

Nevada State Gaming Control Board. (1997-2018). Nevada gaming abstract reports 1997-2018. https:// gaming.nv.gov/index.aspx?page $=144$

Peiser, R., \& Hamilton, D. (2012). Professional real estate development: The ULI guide to the business. Urban
Land Institute.

Photograph of the front of Wilbur Clark's Desert Inn (Las Vegas), 1950s. [ca. 1950s]. [Photograph]. Dreaming the skyline: Resort architecture and the new urban space (Digital ID sky000039). University of Nevada, Las Vegas University Libraries, Las Vegas, NV, USA. https://d.library.unlv.edu/digital/ collection/sky/id/62/rec/1

Pollack, A. (1997, November 13). Building a classier image: Las Vegas hotels woo blue chip visitors. The New York Times. https://www.nytimes.com/ 1997/11/13/business/building-a-classier-image-lasvegas-hotels-woo-blue-chip-visitors.html

Rothman, H. (2003). The instant metropolis. In H. Rothman (Ed.), Neon metropolis. How Las Vegas started the twenty-first century (pp. 261-288). Routledge.

Russo, G. (2006). Supermob: How Sidney Korshak and his criminal associates became America's hidden powerbrokers. Bloomsbury.

Savini, F. (2021). Towards an urban degrowth: Habitability, finity and polycentric autonomism. Economy and Space A, 53(5), 1076-1095. https://journals.sagepub. com/doi/pdf/10.1177/0308518X20981391

Schumpeter, J. (1942). Capitalism, socialism and democracy. Harper and Brothers.

Second tower planned. (2004, February 13). Las Vegas Sun. https://lasvegassun.com/news/2004/feb/13/ second-tower-planned

Stein, J. (2004, July 26). The strip is back! Time Magazine. http://content.time.com/time/subscriber/article/ 0,33009,994712,00.html

Stevenson, D. (2012). The city. Polity Press.

Strow, D. (2000, April 28). Wynn buys D.I. Las Vegas Sun. https://lasvegassun.com/news/2000/apr/28/wynnbuys-di

Thompson, G. (1999, May 18). Desert Inn is sold. Las Vegas Sun. https://lasvegassun.com/news/1999/ may/18/desert-inn-is-sold

Vance, J. (1990). The continuing city: Urban morphology in western civilization. Johns Hopkins University Press.

Weber, R. (2002). Extracting value from the city: Neoliberalism and urban redevelopment. Antipode, 34(3), 520-540.

Weber, R. (2015). From boom to bubble: How finance built the new Chicago. University of Chicago Press.

Wood, D. (2005, April 28). Las Vegas glitz dulled by growing pains. The Christian Science Monitor. https:// www.csmonitor.com/2005/0428/p01s02-ussc.html

Wynn plans new Strip resort. (2000, June 8). Las Vegas Sun. https://lasvegassun.com/news/2000/jun/08/ wynn-plans-new-strip-resort

Wynn Resorts Limited. (2003-2019). Form 10-K annual reports for the fiscal years ending December 31, 2002-December 31, 2018. United States Securities and Exchange Commission. https://www.sec.gov/ edgar/browse/?CIK=1174922\&owner=exclude

Wynn tells all about Desert Inn deal, his future. (2000, 
July 2). Las Vegas Sun. https://lasvegassun.com/ news/2000/jul/02/wynn-tells-all-about-desert-inndeal-his-future
Xue, J. (2021). Urban planning and degrowth: A missing dialogue. Local Environment. https://doi.org/ 10.1080/13549839.2020.1867840

\section{About the Author}

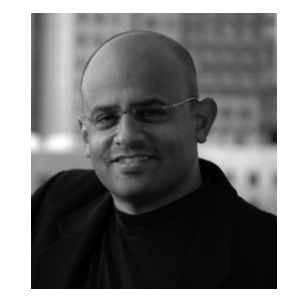

Aseem Inam (PhD) is the inaugural chair in urban design and professor at Cardiff University, and founding director of the research-based practice TRULAB: Laboratory for Designing Urban Transformation. $\mathrm{He}$ is the author of the books Planning for the Unplanned and Designing Urban Transformation. He has carried out numerous funded research projects and published peer-reviewed scholarly articles in international journals on urbanism, urban practice, and urban transformation. He has practiced as an award-winning urbanist in Brazil, Canada, France, Greece, India, Morocco, the United Kingdom, and the United States. 